\title{
Deconstructing Bataille: The sacred and the profane
}

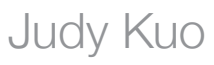

\section{Introduction}

This essay explores Georges Bataille's analysis of the fundamental duality of the irrational sacred, and the rational profane in human experience, revaluating the centrality of terror and awe in social functioning. By reimagining the significance of the sacred in the functioning of rational life, Bataille challenges classical conceptions of rationality and irrationality, principally those within the work of Max Weber. This essay first analyses the essential duality of the sacred heterogeneity and profane homogeneity of human experience, and the fundamental centrality of the excessive within rational life. Then through a deconstruction of the sacred and profane, I suggest a necessary interrelation of mutual dependence and perpetuation between these opposing concepts. Using this deconstructive interpretation, I put forward a critique of the classical conception of this dichotomy as portrayed in Weber's 'disenchantment', which is finally illustrated through an analysis of the hospital as a site in which these social forces manifest. 


\section{The essential duality of social life}

In Bataille's analysis of both social life and human condition, the irrational drive to consume and destroy is contrasted with the rational desire to maintain a homogenous order in our perception of the world. Through the inexorable duality of 'the realm of calm and rational behaviour and the violence of the sexual impulse' in human experience, ${ }^{1}$ Bataille reveals the opposing yet interlocked relationship that places the sacred at the centre of social functioning. For Bataille, the sacred encompasses that element of 'inner experience' whose opacity defies any homogenous social structure or knowledge. It disrupts order, and tempts us toward destruction, in its irreducible heterogeneity - in its 'useless expenditure', 'waste and destruction'. ${ }^{2}$ The 'radical centrality of a heterogeneous will to expend and destroy' is the definitive core of the social that 'simply is ... as a fact of social life' that today's rational life wants to disregard. ${ }^{3}$ It is this excess that '[incite] disgust and veneration ... which both constitute and threaten the everyday world', ${ }^{4}$ which becomes sacred. Yet despite this 'rational world' which man has 'built up', ${ }^{5}$ the sacred eternally returns as 'a sickness' in spite of any attempt to achieve its rational suppression. ${ }^{6}$ The sacred is radically beyond in this way, evading definition, limitation, or rationalisation, yet invariably central to human existence.

The affirmation of these instincts towards the excessive and irrational, which constantly throws the rational world out of balance, is what Bataille and the Collège de Sociologie sought to reinvigorate within their focus on 'sacred sociology'. Rather than accepting the modernist authority of the rational, the Collège emphasises that 'a homogenous society leads to the destruction of the idea of religion and so denies the sacred', and thus

1 Georges Bataille, Death and Sensuality: A Study of Eroticism and the Taboo (New York: Walker and Company, 1962), 53.

2 Tiina Arppe, 'Sacred Violence: Girard, Bataille and the Vicissitudes of Human Desire', Distinktion: Scandinavian Journal of Social Theory, Vol. 10, No. 2 (2009): 41.

3 William Ramp, 'Religion and the dualism of the social condition in Durkheim and Bataille', Economy and Society, Vol. 32, No. 1 (2003): 125-27.

4 Ramp, 'Religion and the dualism of the social condition in Durkheim and Bataille', 129.

5 Bataille, Death and Sensuality, 40.

6 Friedrich Nietzsche, The Gay Science, trans. W. Kaufmann (New York: Vintage Books, 1974), 236. 
'denies itself' ${ }^{7}$ For Bataille, it is precisely 'to the extent that [we] participate in a sacred horror, that [we] become human', ${ }^{8}$ as it is our continual failure to come to terms with heterogeneity that lies at the foundations of human being and society. In forcing irrationality into the peripheries of irrelevance, we deny the foundation of social being that is the sacred. As such, the Collège sought to affirm this 'unproductive expenditure ... énergie excédente [exceeding energy] ${ }^{\prime},{ }^{9}$ where life is experienced at its limits, with acknowledgement of the necessary centrality of irrationality in social life.

In contrast to the sacred realm, the world of the profane is the realm of the social where there is guarantee of 'the stability of meanings', of definition and order, of homogeneity in understanding. ${ }^{10}$ The modern processes of rationalisation and secularisation, in this way, becomes the development of 'a servile human species, fit only for the fabrication, rational consumption, and conservation of products', ${ }^{11}$ which strives in every attempt to subsume the irrational to the rational, the unknowable to the known. By this definition, the profane is everything we come to know as hierarchy, order, knowledge, language, and institution. As such, what is 'vague, difficult to grasp', or ultimately violent against order, becomes taboo, 'preventing the invasion of [the sacred] in ... profane, orderly existence'.${ }^{12}$ Thus the function of taboos is to omit violence or excess from established order - 'its shape and its objects do change ... but ... violence, terrifying yet fascinating, is what [taboo] is levelled at'. ${ }^{13}$ Profane life is therefore a means by which we cope with the abyss of the chaotic and unknown, which constitutes the backdrop upon which profane rationality is both founded and perpetually disrupted. This disruption is exemplified by our anxiety and uncertainty about the meaning of death provoked by liminal phenomena. For example,

7 Michael Richardson, Georges Bataille (New York: Routledge, 2005), 37.

8 Georges Bataille, 'The Place of Violence: Selected Writings', Parallax, Vol. 6, No. 2 (2000): 88

9 Steven Shaviro, Passion \& Excess: Blanchot, Bataille, and Literary Theory (Gainesville: University Press of Florida, 1990), 45-6.

10 Denis Hollier, 'The Dualist Materialism of Georges Bataille', Yale French Studies, No. 78 (1990): 132.

11 Georges Bataille, 'The use value of D. A. F. de Sade', in Visions of Excess: Selected Writings, eds. A. Stoekl, trans. A. Stoekl, C.R. Lovitt \& D. Leslie Jr (Minneapolis: University of Minnesota Press, 1985), 97.

12 Arppe, 'Sacred Violence', 43.

13 Bataille, Death and Sensuality, 51. 
the liminal phenomenon of death spurs scientific debate over the question of whether cessation of heart/lung function or brain function constitutes death. ${ }^{14}$ For Bataille, this inherent tension between the profane and sacred in social life and human experience defines the way in which we make meaning - we cannot do without either of them. As such, the profane always attempts to construct order on the backdrop of the chaotic sacred and human beings must constantly experience this constant tension.

Ultimately, Bataille and the Collège de Sociologie as a whole challenge the supremacy of rationality within social life, as the sacred is reimagined as a centre of heterogeneity upon which homogenous structures emerge. Thus, profane rationality must perpetually negotiate with and fail to reconcile the abyss of the sacred, which continually disturbs the profane in its overflowing excess and impenetrability, in the very foundations of social life.

\section{Intertwining the sacred and the profane}

Deconstructing the dichotomy of the sacred and the profane (to take inspiration from the 'deconstructive' works of Derrida, Nancy, and Agamben), the complex relationship between these conceptual oppositions is revealed to be one of symbiotic interdependence, wherein the opposition of the sacred and the profane define each other - in deconstructing the two concepts we find that the sacred and the profane are intrinsically tied up in one another For Bataille, the sacred corresponds to 'elements that are impossible to assimilate' in their very excess, ${ }^{15}$ and in this way, must rest on its exclusion from assimilation into the profane. As Bataille writes,

14 Steven Laureys, 'Death, unconsciousness, and the brain', Nature Reviews Neuroscience, No. 6 (2005): 900.

15 Georges Bataille, 'The psychological structure of fascism', in Visions of Excess: Selected Writings, ed. A. Stoekl, trans. A Stoekl, C.R. Lovitt \& D. Leslie Jr (Minneapolis: University of Minnesota Press, 1985), 140. 
'the possible, so it seems, exists at the limit of the impossible'. ${ }^{16}$ This notion of the limit, 'the ineffable or the unspeakable', ${ }^{17}$ provides explanation for the perpetuated yet clashing relationship between sacred and profane.

Because the sacred itself is inexplicable, it is thus established on a notion of what it cannot be reduced to; its exteriority to the profane, as the disgust and horror of the sacred renders it indigestible. To touch on a previous example, death is ultimately sacred in that it cannot be understood by individuals in any way apart from its exteriority to life, as death is absolutely beyond any experience of being, by definition. It is thus by condition of its irreducibility to the profane that the sacred maintains its essential exteriority. The sacred is precisely defined as that which constantly escapes the grasp of homogeneity, and in the same way, the possibility of the sacred emerges at the limit of its impossibility, of its ineffability and 'unknowability'.

In the same way, the profane, constituted by the 'commensurability of all elements ... in productive, namely, useful society', ${ }^{18}$ is correspondingly centered on its foundations in the irrational. In the human will to rationalise, measure, and control, it is that which is not yet assimilated that prompts this drive to make order. It is in the human need to make sense of a world of chaos that our desire to homogenise and make things known is activated. For instance, it is only in incomprehension of the random, disordered phenomena that probability becomes a concern for human beings (who, in attempting to measure chance, reduce unpredictability to its opposite). Moreover, this interrelation of sacred and profane is reflected by the role of the taboo within social life. Taboos function for the profane as they protect homogenous social life from the violent disruption of the sacred, '[removing] the object of taboo from our consciousness', eliminating the unassimilable. ${ }^{19}$ As such, the profane is only preserved through a deliberate awareness of sacred heterogeneity, rather than ignorance or disregard for the sacred. It is at this limit of the rational/ irrational that taboos are activated, and it is precisely at this limit that the

16 Georges Bataille, The Unfinished System of Nonknowledge, ed. S. Kendall, trans. M. Kendell \& S. Kendell (Minneapolis: University of Minnesota Press, 2004), 19.

17 Christopher Stanley, 'Bataille's Communication at and After the Limit of the Law', International Journal for the Semiotics of Law, Vol. 11, No. 32 (1998): 157.

18 Bataille, 'The psychological structure of fascism', 137-38.

19 Bataille, Death and Sensuality, 38. 
boundaries of the profane are established. The continuation of the rational is thus only made meaningful on an implicit background of the irrational. It is therefore in this opposition between the sacred and profane that the rational structures of social life are 'continually renewed and threatened by the excess at its centre', ${ }^{20}$ as both concepts are founded upon each other. In this way, the heterogeneous sacred and the homogenous profane are not in hostile antagonism, but must instead be defined by the limits of their own impossibility in their opposites.

\section{A critique of Weber's 'Disenchantment'}

In this analysis of the sacred and profane as both fundamental elements of the human social condition, and as inherently involved in each other's animation, I critique Weber's classical conception of the irrational and rational as mutually exclusive elements of social life - an idea embedded in his conception of 'disenchantment'. In this section, I relate Bataille's dichotomy of the sacred and profane to Weber's rationalisation and irrational 'magic' of life, and suggest that my deconstruction of these oppositions challenge Weber's conception of the sacred and profane as fundamentally incompatible.

For Weber, modern life is characterised by a disenchantment prompted by the 'development of rationalization' and the intellectualisation of all aspects of life, in the 'erosion of religious powers'. ${ }^{21}$ He argues that 'one need no longer have recourse to magical means ... to master of implore the spirits' in modern society, as the rise of science and capitalism gives way to 'technical means and calculations' to 'master all things by calculation'. ${ }^{22}$ According to Weber, "rationalization' is thus measured negatively in terms of the degree to which magical elements of thought are displaced', suggesting that magic must be sacrificed to make way for the rational, as the irrational and rational must be directly conflicting. ${ }^{23}$ In this way, Weber

20 Ramp, 'Religion and the dualism of the social condition in Durkheim and Bataille', 128.

21 Bryan Turner, 'Preface to the New Edition', in Max Weber: Essays in Sociology, eds. H.H. Gerth \& C.W Mills (New York: Routledge, 2009), xxvi.

22 Max Weber, 'Science as a Vocation', in Max Weber: Essays in Sociology, eds. H.H. Gerth and C.W. Mills (New York: Oxford University Press, 1946), 139.

23 Hans Gerth \& C. Wright Mills, 'Introduction: The Man and His Works', in Max Weber: Essays in Sociology, eds. H.H. Gerth \& C.W. Mills (Routledge: New York, 1946), 51. 
depicts a mutually negating relation between the rational and irrational, with the rational reigning supreme to the destitution of the irrational and the enchanting.

However, using Bataille's evaluation and the deconstructive analysis above, the irrational sacred and rational profane can be elucidated in this way as a fundamental, irreducible duality in the human condition, in that the conditions of possibility for rationality lies in irrationality, and vice versa. Rather than increasing rationalisation growing in proportion to diminishing magic, Bataille argues that the sacred is the background upon which the profane is constantly interrupted and exceeded - this 'will' does not withdraw when confronted with rationalisation, only reinscribed. Moreover, as the sacred requires the profane for its conditions of possibility (and vice versa), the rationalisation of society must continually invoke the irrational and unknowable, even in opposing it. For example, does the taboo against sex within the workplace not also incite a heightened awareness and attention to what could be considered sexual in the workplace, in spite of (and, I suggest, because of) this very prohibition? In this way, this reading of Bataille offers a critique of Weber's 'disenchantment' by challenging the traditional notion of the absolute separation between the rational and the irrational, questioning the depiction of conceptual dichotomies as mutually negating. Instead, this relationship must be reciprocally intensifying and enabling as they are made meaningful only at the threshold of their impossibility. This interconnected relationship can be observed in many social arenas - in particular, public institutions that handle elements of the sacred and the profane, such as hospitals.

\section{Hospitals: Reinscribing the sacred}

In exploration of the context of the hospital environment, I utilise Bataille's analysis of the function of the sacred and profane to illustrate this critique of Weber and emphasise the manner in which the sacred always remains central to the function of social life, never receding behind the profane.

Through a multiplicity of processes in the hospital, the profane conceals the sacred in favour of an ordered rationality which removes any 'enchantment' from its functioning, excluding the heterogeneous reality upon which it functions. Within the hospital, networks of administrative processes serve to catalogue and categorise all interactions, defined by 
rationalised roles (of patient, doctor, nurse, receptionist). This underscores the 'systematic coherence' of the homogenous profane that reduces human communication to a bureaucratised function, which Weber argues is the root of our 'disenchantment of the world'. ${ }^{24}$ Any conversation engages with a procedural language which concerns the transgressive economy of abundance' of bodies, death, birth, sex, trauma, consumption, ${ }^{25}$ yet removes any vulgarity, or violence, through its scientific technicality. To use a previous example, the hospital is concerned with sex as sexual intercourse, never ' $\mathrm{f}^{* * *}{ }^{\text {ing', }}$ ' or concerned with reproductive organs, never ' $\mathrm{c}^{* *} \mathrm{t}$ ', as used in Bataille's own short stories and novels. In this way, the carnal and destructive sacredness within the hospital is reduced to Weber's notion of 'intellectualisation' and 'rationlization' of human life, safeguarding the profane to the exclusion of attraction or repulsion.

Furthermore, in the physical setting of the hospital itself, the sacred is also always masked by the profane rationality that functioning on a background of a common awareness of the sacrality it hides. Inscribed in its very purpose, the hospital is always concerned with bleeding, secretions, defecation, waste, and regurgitation - sacred excess in all its immanent forms. Nonetheless, hospitals must preserve pretence of sterility, cleanliness, even virtue, by masking the horror and disgust of the sacred that persists beneath the surface. For example, the white partitions and white sheets that hide the corpse pacify our fascination and horror towards death, as the dead body is discreetly deposited at the morgue, without ceremony. Yet it is in recognition of the sacredness and irrationality in these images that motivate this numbing bureaucratisation and technical administration, to diminish it to the profane and rational. In this way, the sacred remains at the heart of the profane, for it is in confronting this endless abyss of the sacred that we are driven to fabricate a sense of order or security for ourselves. As such, the dependence of the profane rationality on the centrality of the sacred challenges Weber's depiction of these opposing elements of social life as being irreconcilable antagonisms that negate each other.

24 Ibid., 51.

25 Stanley, 'Bataille's Communication at and After the Limit of the Law', 157. 
The reanimation of enchanting elements of the hospital, through its imagination in entertainment media, also highlights the perpetual shortcomings of rationalised efforts to eliminate the sacred that merely re-emerges in other manifestations of cultural imagination. In medical dramas such as Grey's Anatomy and House M.D., the main attraction of this form of entertainment is the reinvigoration of the bloodshed and gore of hospital environment. ${ }^{26}$ These sacred excesses remain intensely affective and vivid within the cultural imagination of torture, sex, incest, cannibalism, violence, and vampires, reinscribed within the imagination of the media in shows such as Game of Thrones, Hannibal, and True Blood. In this way, the perpetual, the reanimation of the irrational and the sacred within entertainment media suggests that what Weber calls the increased rationalisation of social life (and what Bataille refers to as the profane) only prompts a reinscription of the sacred in other forms. Thus there is no increased rationality measured in proportion to the impoverishment of the irrational as Weber suggests, as the sacred always evades any constraints of rationality by its overflowing, teeming excess; enduring relentlessly in this way.

\section{Conclusion}

In analysis of Bataille and the Collège de Sociologie's affirmation of the central importance of the sacred - the abyss of excess, attraction, and repulsion - this essay has argued that the profane and the sacred in social life embody an irreducible dualism in which the profane and the sacred both have their conditions of realisation rooted in each other, in their opposites. Using this reading of Bataille, a critique of Weber's 'disenchantment' is explored and expanded, in the context of the hospital as a site of this interaction. It is in this way that the sacred is revealed to be an inherent element of human experience and social life, which is never successfully suppressed by the rational profane, but endures as a 'will' that always reinscribes itself in the social imagination, with a presence as unavoidable as the horror and awe it incites within us.

26 Philippa Roxby, 'Why are medical dramas so popular?' BBC News, 10 November 2012, accessed 2 May 2015, www.bbc.com/news/health-20257541. 


\section{References}

Arppe, T. 'Sacred Violence: Girard, Bataille and the Vicissitudes of Human Desire', Distinktion: Scandinavian Journal of Social Theory, Vol. 10, No. 2 (2009): 31-58.

Bataille, G. Death and Sensuality: A Study of Eroticism and the Taboo. (New York: Walker and Company, 1962).

Bataille, G. 'The psychological structure of fascism', in Visions of Excess: Selected Writings, edited by A. Stoekl, translated by A. Stoekl, C.R. Lovitt \& D. Leslie Jr. (Minneapolis: University of Minnesota Press, 1985a), 137-60.

Bataille, G. 'The use value of D. A. F. de Sade', in Visions of Excess: Selected Writings, edited by A. Stoekl, translated by A. Stoekl, C.R. Lovitt \& D. Leslie Jr. (Minneapolis: University of Minnesota Press, 1985b), 91102 .

Bataille G. 'The Place of Violence: Selected Writings', Parallax, Vol. 6, No. 2 (2000): 81-91.

Bataille, G. The Unfinished System of Nonknowledge, edited by S. Kendall. Translated by M. Kendell \& S. Kendell. (Minneapolis: University of Minnesota Press, 2004).

Gerth, H.H. \& C.W. Mills. 'Introduction: The Man and His Works', in Max Weber: Essays in Sociology, edited by H.H. Gerth \& C.W. Mills. (Routledge: New York, 1946), 3-75.

Hollier, D. 'The Dualist Materialism of Georges Bataille', Yale French Studies, No. 78 (1990): 124-139.

Laureys, S. 'Death, unconsciousness, and the brain', Nature Reviews Neuroscience, No. 6 (2005): 899-909.

Nietzsche, F. The Gay Science. Translated by W. Kaufmann. (New York: Vintage Books, 1974).

Ramp, W. 'Religion and the dualism of the social condition in Durkheim and Bataille', Economy and Society, Vol. 32, No. 1 (2003): 119-140.

Richardson, M. Georges Bataille. (New York: Routledge, 2005). 
Roxby P. 'Why are medical dramas so popular?' $B B C$ News, 10 November 2012. Accessed 2 May 2015. www.bbc.com/news/health-20257541.

Shaviro, S. Passion \& Excess: Blanchot, Bataille, and Literary Theory. (Gainesville: University Press of Florida, 1990).

Stanley C. 'Bataille's Communication at and After the Limit of the Law', International Journal for the Semiotics of Law, Vol. 11, No. 32 (1998): 155-179.

Turner B.S. 'Preface to the New Edition', in Max Weber: Essays in Sociology, edited by H.H. Gerth \& C.W. (Mills. New York: Routledge, 2009), xii$\mathrm{xxx}$.

Weber, M. 'Science as a Vocation', in Max Weber: Essays in Sociology, edited by H.H. Gerth and C.W. Mills. (New York: Oxford University Press, 1946), 129-156. 
This text is taken from Merici, Volume 1, 2015, edited by Henry Poetrodjojo, Ilze Alexander and Lauren Prossor, published 2016 by ANU eView, The Australian National University, Canberra, Australia. 